\title{
Potential Effects of Mina53 on Tumor Growth in Human Pancreatic Cancer
}

\author{
Xiao-ping Tan $\cdot$ Wei-guo Dong $\cdot$ Qing Zhang • \\ Zi-rong Yang $\cdot$ Xiao-fei Lei $\cdot$ Ming-hua Ai
}

Published online: 13 February 2014

(c) The Author(s) 2014. This article is published with open access at Springerlink.com

\begin{abstract}
Myc-induced nuclear antigen (Mina53) is a protein with a molecular weight of $53 \mathrm{kDa}$ expression of which is induced by c-Myc. Increased expression of Mina53 is documented in some human carcinomas. In this study, we found markedly increased Mina53 expression in pancreatic cancer tissue specimens. This expression did not correlate with clinicopathological characteristics, such as sex, age, and presence of distant metastasis. However, there was a statistically significant association with histological differentiation, TNM stage, and lymph node metastases. To study functional role of Mina53, we silenced its expression by siRNA in PANC-1 cells. These cells were arrested in the G2/M phase, and apoptosis rates were increased. In conclusion, increased expression of Mina53 may play an important role in the development of human pancreatic cancer. Mina53 can be used as a marker for pancreatic cancer and may potentially be exploited as a target for treatment of pancreatic cancer.
\end{abstract}

Keywords Mina53 - Pancreatic cancer - RNA interference $\cdot$ Quantum dots · Tumor growth

\section{Introduction}

Pancreatic cancer is a highly aggressive and deadly disease. Worldwide, more than 250,000 people die annually of

\section{Tan $(\bowtie) \cdot$ Q. Zhang}

Department of Gastroenterology, No. 1 Hospital, Yangtze

University, Jingzhou 434000, Hubei, People's Republic of China

e-mail: xiaopingyanli@126.com

X. Tan $\cdot$ W. Dong $\cdot$ Z. Yang $\cdot$ X. Lei $\cdot$ M. Ai

Department of Gastroenterology, Renmin Hospital, Wuhan

University, Wuhan 430060, Hubei, People's Republic of China pancreatic cancer [1]. Pancreatic cancer refers to a malignant neoplasm originating from transformed cells resident to pancreatic tissues. The most common type of pancreatic cancer, which accounts for $95 \%$ of these tumors, is adenocarcinoma, which is a tumor exhibiting glandular architecture on light microscopy. Adenocarcinomas arise from the exocrine component of the pancreas [2]. A minority of tumors arises from islet cells and is classified as neuroendocrine tumors. Most patients are diagnosed at an advanced stage of the disease, and the incidence and mortality rates for invasive pancreatic cancer are almost identical [3]. Treatment has not improved significantly during the past few decades and is still insufficiently effective in increasing survival of these patients [4-6]. Therefore, a better understanding of carcinogenesis of pancreatic cancer and its prevention are recognized as important factors in reducing mortality worldwide.

The Myc family of proto-oncogenes consists of three main genes: c-Myc, N-Myc, and L Myc [7]. Abnormal expression of Myc family genes has long been known to be associated with neoplastic diseases in a wide range of vertebrates, including humans. Besides cancerogenesis, the genes of the Myc family are also involved in many other biological processes. Specifically, in addition to cell proliferation, these genes also control apoptosis and cell differentiation. c-Myc is one of the most widely studied protooncogenes. In general, its increased expression is associated with cell proliferation, while the expression is downregulated in quiescent and differentiated cells.

The proteins encoded by the Myc family genes are members of the basic helix-loop-helix leucine zipper transcription factors and appear to control expression of several other genes that mediate each of the Myc functions. However, unidentified Myc target genes may still exist, and the mechanisms by which Myc contributes to tumorigenesis are still not fully understood [8-15]. 
Myc-induced nuclear antigen (Mina53) is a protein with a molecular weight of $53 \mathrm{kDa}$ expression of which is directly induced by c-Myc $[16,17]$. The protein is predominantly localized in the nucleus, although some of the protein is also expressed in the nucleolus [16-19]. Expression of Mina53 is increased during cell proliferation, and specific inhibition of Mina53 expression by RNA interference (RNAi) suppresses cell proliferation [18]. Recently, a monoclonal antibody against human Mina53 protein was generated. Using this antibody, increased expression of Mina53 was documented in some human carcinomas [18-27], such as colon carcinoma and esophageal squamous cell carcinoma. These data suggest that Mina53 may be associated with carcinogenesis.

In the present study, we evaluated expression of Mina53 in pancreatic ductal adenocarcinomas and further studied the relationship between its expression and clinicopathological characteristics of human pancreatic cancer. Further, using RNAi, we evaluated the role of Mina53 in the carcinogenesis and progression of tumor to test the potential clinical usefulness of Mina53 as target for anti-cancer therapies.

\section{Materials and Methods}

\section{Tissue Microarray (TMA)}

TMA was constructed from a series of paraffin-embedded specimens including 96 cases of pancreatic ductal adenocarcinomas and 34 specimens of normal pancreatic tissue that were collected from 2006 to 2011 at the Pathology Departments of Renming Hospital of Wuhan University and Jingzhou First People's Hospital in China. Tissue specimens were arranged in 20 columns and 12 rows for a total of 200 individual cores $(1.1 \mathrm{~mm}$ and $4 \mu \mathrm{m})$. Each sample had two replicates on the TMA. Each slide had more than $95 \%$ tissue core retention. Clinicopathological characteristics of 96 pancreatic cancer cases were as follows: mean age 49.2 years (range 32-80), 61 male and 35 female patients, 28 cases of stage I, 43 cases of stage II, 15 cases of stage III, and 10 cases of stage IV according to pathological TNM staging.

\section{Quantum Dot-Based Immunofluorescence}

Histochemistry (QDs-IHC)

The 4- $\mu \mathrm{m}$ thick TMAs were deparaffinized in xylene and rehydrated in graded ethanol. QDs-IHC was performed according to the manufacturer's instructions (Wuhan Jiayuan Quantum Dot Co LTD, Wuhan, China). Antigen retrieval was performed in citric acid $(10 \mathrm{mM}$ and $\mathrm{pH}$ 6.0) at $95{ }^{\circ} \mathrm{C}$ for $10 \mathrm{~min}$, followed by cooling for $30 \mathrm{~min}$. For antibody binding, TMAs were first incubated with $2 \%$ bovine serum albumin (BSA) buffer (Sigma, St. Louis, USA) for $30 \mathrm{~min}$ at $37{ }^{\circ} \mathrm{C}$ followed by overnight incubation at $4{ }^{\circ} \mathrm{C}$ with primary mouse anti-human Mina53 monoclonal antibody (dilution 1:100, Invitrogen, San Francisco, USA). TMAs were then washed $3 \times 5$ min with TBS-T $(0.5 \%$ Tween, $0.1 \mathrm{M}$ Tris-base, and $0.9 \% \mathrm{NaCl}$; $\mathrm{pH}$ 7.6) and incubated with biotinylated goat anti-mouse IgG (dilution 1:100, Jackson ImmunoResearch, West Grove, USA) for $30 \mathrm{~min}$ at $37^{\circ} \mathrm{C}$. Negative control samples were prepared in parallel by replacing primary antibody with TBS. For QDs conjugation, antibody-binding TMAs were again incubated in $2 \%$ BSA buffer for $10 \mathrm{~min}$ at $37{ }^{\circ} \mathrm{C}$, incubated with QDs $(605 \mathrm{~nm})$, and conjugated to streptavidin (QDs-SA) (dilution 1:200 in $2 \%$ BSA, Wuhan Jiayuan Quantum Dot Co LTD, Wuhan, China) for $30 \mathrm{~min}$ at $37^{\circ} \mathrm{C}$. The specimens were rinsed $3 \times 5$ min with TBS-T and sealed with $90 \%$ glycerine (Sigma-Aldrich, St. Louis, USA).

QD signals were detected using Olympus BX51 fluorescence microscope equipped with Olympus Micro DP 72 camera (Olympus Corporation, Tokyo, Japan). Signals were red, bright, target specific, and photostable. At least one hundred cells from five representative fields of each core were randomly selected and counted blindly by two independent observers using a $40 \times$ objective. Mina53 expression was assessed semi-quantitatively and classified into three groups on an arbitrary scale of 0,1 , and 2 [28]. Specifically, percentage of positively stained tumor cells and staining intensity were recorded for each sample. A value of zero was assigned to specimens with fewer than $10 \%$ positive cells, 1 represented weak homogeneous staining, and 2 was given to specimens with intense staining.

\section{Cell Culture}

Human pancreatic cancer cell line PANC-1 was maintained in RPMI 1640 (Invitrogen) supplemented with $10 \%$ fetal bovine serum, 100 units $/ \mathrm{ml}$ penicillin and $100 \mu \mathrm{g} / \mathrm{ml}$ streptomycin in a humidified incubator at $5 \% \mathrm{CO}_{2}$ and $37{ }^{\circ} \mathrm{C}$.

\section{Cell Transfection}

Mina53 siRNAs were designed using BLOCK-iT ${ }^{\mathrm{TM}}$ RNAi Designer (Invitrogen) using accession number from Gene bank. siRNA were synthesized by Jima Bio. Corp. (Shanghai, China). The target sequences were as follows: sense $5^{\prime}$-GCCGGAUCAAGAUCAAUCUTT- $3^{\prime}$ and antisense $5^{\prime}$-AGAUUGAUCUUGAUCCGGCTT- ${ }^{\prime}$. Negative control siRNA (i.e., nontargeting siRNA) was purchased from Jima Bio. Corp. 
PANC-1 cells were seeded onto collagen I-coated sixwell plates at cell density of $5 \times 10^{4}$ cells/well and cultured overnight. The following day, cells were transferred in serum-free medium and transfected with siRNA using Lipofectamine 2000 (Invitrogen) for $4 \mathrm{~h}$ at $5 \% \mathrm{CO}_{2} /$ $37^{\circ} \mathrm{C}$. After 4-hour incubation, an equal volume of medium supplemented with $20 \%$ FBS was added to wells, and transfected cells were cultured until further analyses.

\section{Proliferation Assays}

Cells were transiently transfected with Mina53 siRNA and counted using trypan blue staining. After about $5 \times 10^{3}$ cells were cultured, the number of cells was counted at indicated time points. The experiments were repeated three times.

\section{Real-Time RT-PCR}

The levels of Mina53 mRNA after transfection were quantified by real-time RT-PCR. Total RNA was isolated from PANC-1 cells using TRIzol (Invitrogen). RNA concentration was determined using NanoDrop 2000 Spectrophotometer. $1 \mu \mathrm{g}$ total RNA was reverse transcribed with MuLV reverse transcriptase (Roche Molecular Systems Inc., Branchburg, USA) at $37{ }^{\circ} \mathrm{C}$ for $60 \mathrm{~min}$. The cDNAs were utilized in SYBR Green real-time PCR. Each $20 \mu \mathrm{l}$ of PCR reaction contained $2 \mu \mathrm{l}$ cDNA, $2 \mu \mathrm{l}$ $10 \times$ LightCycler-DNA Master Mix SYBR Green I (Roche Diagnostics Corp., Indianapolis, USA), and $1 \mu \mathrm{M}$ forward and reverse primers. The primer sets were as follows: $5^{\prime}$-CCCATTATGATGATGTCGA- $3^{\prime}$ (sense) and 5'TGTTCTGGTAGGTGCTGAT- $3^{\prime}$ (antisense). Real-time PCR was performed using the LightCycler ${ }^{\mathrm{TM}}$ V3 System (Roche Diagnostics Corp). The PCR conditions were as follows: 35 cycles of $2 \mathrm{~s}$ each at $95{ }^{\circ} \mathrm{C}, 10 \mathrm{~s}$ at $55^{\circ} \mathrm{C}$, and $15 \mathrm{~s}$ at $72{ }^{\circ} \mathrm{C}$. Expression of $\beta$-actin mRNA was used as control.

\section{Western Blot}

To detect protein level of Mina53 after transfection, PANC-1 cells were treated with siRNA as above, washed with PBS, and lysed in RIPA buffer containing protease inhibitor cocktail. The lysates were centrifuged and supernatants collected. Protein concentrations were determined using Bio-Rad Protein Assay (Bio-Rad, Hercules, USA). Protein extracts $(40 \mu \mathrm{g})$ were separated on $12.5 \%$ SDS-PAGE. The proteins were transferred onto nitrocellulose membranes. The membranes were blocked using $5 \%$ nonfat dry milk and incubated overnight at $4{ }^{\circ} \mathrm{C}$ with primary antibodies (anti-Mina53 or anti-actin; both from Santa Cruz Biotechnology, Santa Cruz, CA, USA), followed by incubation with HRP-conjugated secondary antibodies for $1 \mathrm{~h}$ at room temperature. Membranes were developed using ECL Substrate (Amersham Corp., Arlington Heights, USA). Protein bands were visualized on X-ray film.

\section{Cell Cycle and Apoptosis Analysis}

The analysis of cell cycle was performed as follows. At indicated times after transient transfection of PANC-1 cells with Mina53 siRNA, floating cells were collected by pipetting and adherent cells by trypsinization. Both cells were combined and fixed with $2 \%$ paraformaldehyde followed by permeabilization with $70 \%$ ethanol. Cells were treated with RNase A $(0.25 \mathrm{mg} / \mathrm{ml})$ at $37{ }^{\circ} \mathrm{C}$ for $30 \mathrm{~min}$ and stained with propidium iodine $(50 \mu \mathrm{g} / \mathrm{ml})$. Cellular DNA content was analyzed using flow cytometer (BD Biosciences, Franklin Lakes, USA). Cell cycle profiles were determined with CELLQuest ${ }^{\mathrm{TM}}$ software (BD Biosciences). For apoptosis analysis, cells were simultaneously stained with Annexin V and propidium iodide kit (BD Biosciences) according to the manufacturer's instructions. Stained cells were analyzed by flow cytometry to quantify the number of apoptotic cells.

\section{Statistical Analyses}

For data compilation and statistical analysis, the software package SPSS version 13.0 was used (SPSS Inc, Chicago, USA). The Chi-square and Fisher's exact probability tests were used to examine associations between Mina53 expression and various other parameters including clinicopathological characteristics. Number of colonies was compared between PANC-1 cells transiently transfected by Mina53 siRNA using the Student's $t$ test. Statistical significance was assumed at a $P$ value $<0.05$.

\section{Results}

Mina53 Expression in Normal Pancreatic Tissue and Pancreatic Ductal Adenocarcinoma

Positive Mina53 staining was mainly localized in nuclei and, to a certain degree, in cytoplasm (Fig. 1). Normal pancreatic specimens showed positive staining for Mina53 in only two out of 34 cases (5.9\%). By contrast, overexpressed Mina53 was found in 81 of the 96 adenocarcinoma specimens (84.4\%; Table 1$)$.

Expression of Mina53 in tumor specimens was compared to expression in normal pancreatic tissue. Mina53 expression was significantly higher in adenocarcinomas compared with normal specimens $(P<0.01$, Table 1$)$. 
Fig. 1 Expression of Mina53 in TMA of pancreatic cancer and normal pancreatic tissue specimens. a Positive expression in pancreatic cancer tissue $(\times 200)$. b Positive expression in pancreatic cancer tissue $(\times 400)$ c Negative expression in normal pancreatic tissue $(\times 200)$
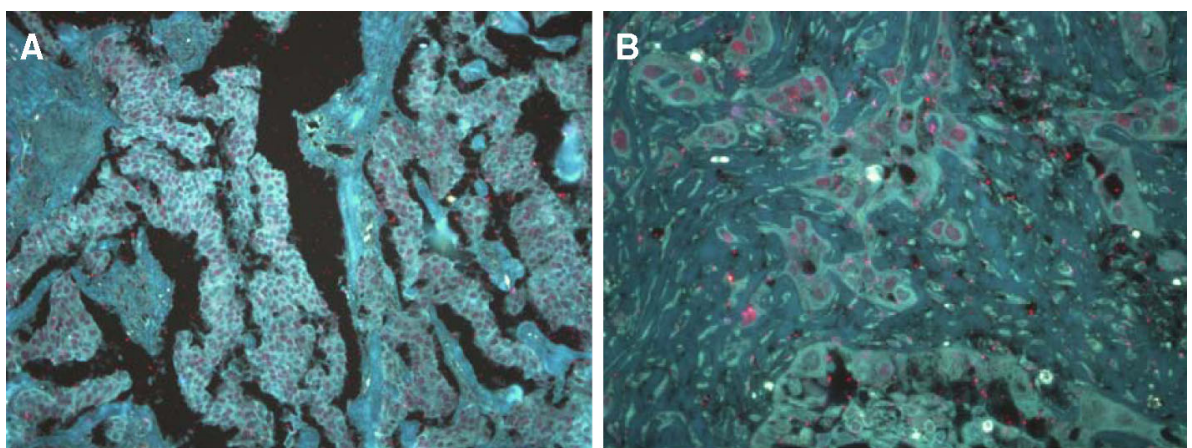

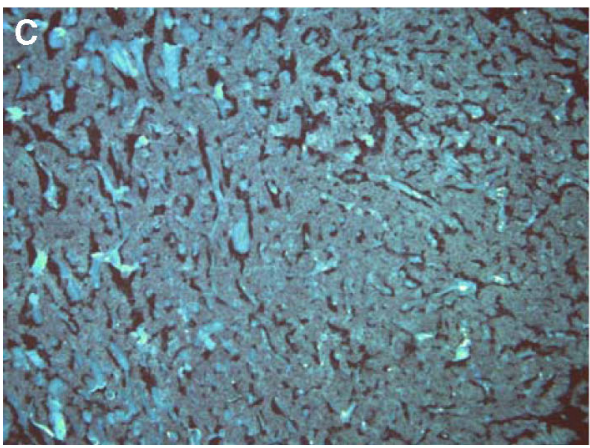

Table 1 Mina53 expression in human normal pancreatic tissue and pancreatic ductal adenocarcinoma

\begin{tabular}{lllll}
\hline Groups & Total & Negative & Positive & $\begin{array}{l}\text { Cases with } \\
\text { positive staining }\end{array}$ \\
\hline $\begin{array}{c}\text { Normal pancreatic } \\
\text { tissue }\end{array}$ & 34 & 32 & 2 & $3(5.9 \%)$ \\
$\begin{array}{c}\text { Pancreatic ductal } \\
\text { adenocarcinoma }\end{array}$ & 96 & 15 & 81 & $83(84.4 \%)$ \\
\hline
\end{tabular}

Relationship Between Mina53 Expression and Clinicopathological Characteristics of Pancreatic Cancer

There were no significant associations between Mina53 overexpression and clinicopathological characteristics, such as sex and age (Table 2). By contrast, there was a statistically significant association with histological differentiation $(P<0.05)$, TNM stage $(P<0.01)$, and lymph node metastasis $(P<0.05)$. Significant associations between Mina53 and distant metastasis were not found (Table 2).

Effect of Mina53 siRNA Silencing on Expression of Mina53

Human Mina53 siRNA and negative control siRNA were successfully constructed as confirmed by sequencing. Pancreatic cancer cells (PANC-1) were transfected with
Table 2 Relationship between expression of Mina53 and clinicopathological characteristics of pancreatic cancer

\begin{tabular}{|c|c|c|c|c|}
\hline \multirow[t]{2}{*}{ Clinical characteristics } & \multirow[t]{2}{*}{ Total } & \multicolumn{2}{|l|}{ Mina53 } & \multirow[t]{2}{*}{$P$} \\
\hline & & Negative & Positive & \\
\hline All cases & 96 & 15 & 81 & \\
\hline \multicolumn{5}{|l|}{ Sex } \\
\hline Male & 61 & 8 & 53 & \multirow[t]{2}{*}{0.371} \\
\hline Female & 35 & 7 & 28 & \\
\hline \multicolumn{5}{|l|}{ Age } \\
\hline$\leq 60$ years & 49 & 9 & 40 & \multirow[t]{2}{*}{0.450} \\
\hline$>60$ years & 47 & 6 & 41 & \\
\hline \multicolumn{5}{|c|}{ Histological differentiation } \\
\hline Well & 28 & 8 & 20 & \multirow[t]{3}{*}{0.025} \\
\hline Moderate & 39 & 5 & 34 & \\
\hline Poor & 29 & 2 & 27 & \\
\hline \multicolumn{5}{|l|}{ TNM stage } \\
\hline I & 11 & 6 & 5 & \multirow[t]{4}{*}{0.004} \\
\hline II & 43 & 6 & 33 & \\
\hline III & 32 & 2 & 30 & \\
\hline IV & 10 & 1 & 9 & \\
\hline \multicolumn{5}{|c|}{ pN (lymph node metastasis) } \\
\hline pNO & 22 & 7 & 15 & \multirow[t]{2}{*}{0.017} \\
\hline $\mathrm{pN} 1$ & 74 & 8 & 66 & \\
\hline \multicolumn{5}{|l|}{ Distant metastasis } \\
\hline M0 & 86 & 15 & 71 & \multirow[t]{2}{*}{0.354} \\
\hline M1 & 10 & 0 & 10 & \\
\hline
\end{tabular}




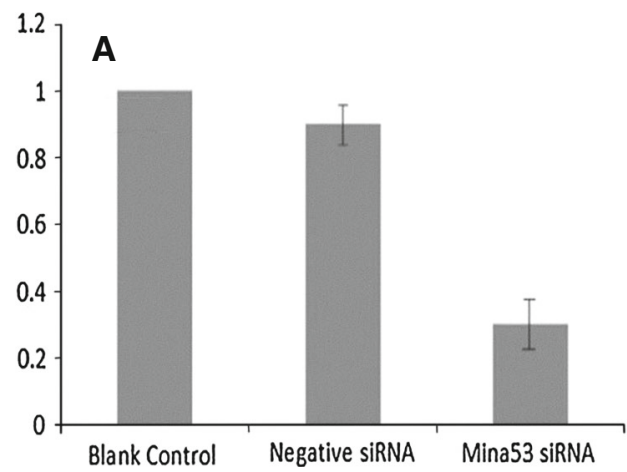

Fig. 2 Expression of Mina53 after siRNA silencing. a Expression of Mina53 was down-regulated by siRNA. Relative expression was calculated as equivalent ratio (mRNA levels of the gene of interest corrected for $\beta$-actin mRNA) using the expression in blank control

siRNA. The siRNA silencing led to a decrease of Mina53 mRNA levels of $35.1 \pm 2.7 \%$ ( $P<0.01$ vs. blank control group; Fig. 2a). By contrast, no significant difference was found in Mina53 mRNA levels between negative siRNA and blank control groups (Fig. 2a). Further, diminished expression of Mina53 in Mina53 siRNA group was confirmed by Western blotting (Fig. 2b).

\section{Mina53 siRNA Silencing Diminishes Cell Proliferation}

To further analyze the role of Mina53 in carcinogenesis, we examined the effect of Mina53 siRNA silencing on pancreatic cancer cell proliferation. After $72 \mathrm{~h}$ post-transfection, cells treated with Mina53 siRNA exhibited significantly diminished growth rates compared with blank control cells (no siRNA) or cells transfected with negative siRNA. As shown in Fig. 3, negative siRNA had a minimal effect on proliferation of PANC-1. By contrast, silencing of Mina53 significantly suppressed proliferation in PANC-1 cells (Fig. 3). After 48 and $72 \mathrm{~h}$ post-siRNA, there was an inhibition of the growth of PANC-1 cells (respectively, 40 and $35 \%, P<0.01$; Fig. 3).

\section{Mina53 siRNA Induces Apoptosis}

Cell cycle distribution and apoptosis after transfection were detected by flow cytometry. There was no significant difference in cell cycle distribution between blank control and negative siRNA groups (Table 3). Apoptosis rates in both groups were low.

Twelve hours post-transfection, cell cycle distribution, and apoptosis in Mina53 siRNA group were similar to blank control group (Table 3). Although apoptosis was not apparent, the distribution of cell cycle began to change, such that the proportion of cells arrested in $\mathrm{G} 2$ phase declined while that of cells in M phase increased (Table 3). Cell cycle

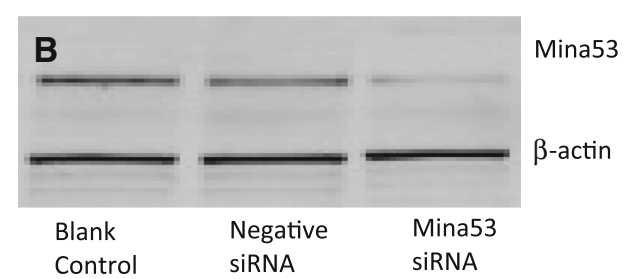

group as control. The dotted line (relative expression $=1$ ) indicates expression level in blank control group. Data are presented as mean \pm SD of three experiments. b The Western blot analysis confirmed diminished expression of Mina53 protein

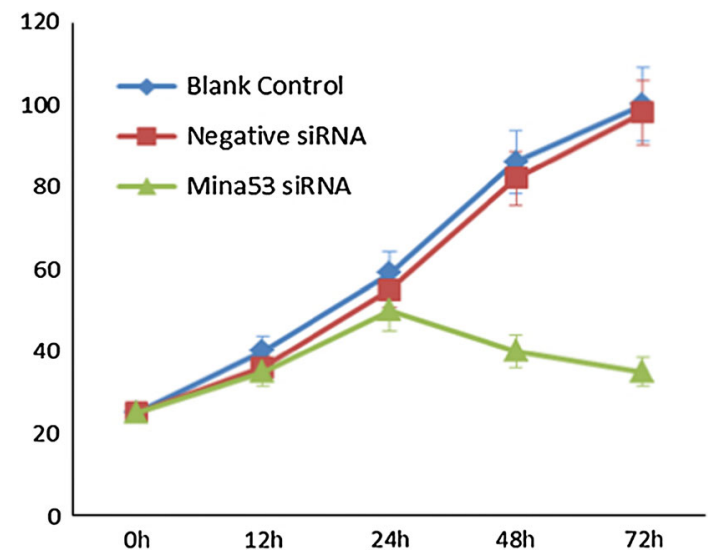

Fig. 3 Proliferation of pancreatic cancer cells after Mina53 siRNA silencing. After 48 and $72 \mathrm{~h}$ post-transfection, cells treated with Mina53 siRNA exhibited significantly diminished growth rates compared with blank control cells (no siRNA) or cells transfected with negative siRNA

distribution and apoptosis of Mina53 siRNA group at 48 and $72 \mathrm{~h}$ post-transfection demonstrated that the proportion of cells arrested in G2/M phase was about 1.5 times higher than in blank control group, while apoptosis rates were, respectively, $19.3 \pm 2.8$ and $38.9 \pm 2.9 \%(P<0.05$ Mina53 siRNA vs. blank control or negative siRNA groups; Table 3).

\section{Discussion}

Tsuneoka et al. $[16,17]$ previously isolated Mina53 as a Myc target gene and showed a clear relationship between Mina53 expression and cell proliferation. Immunohistochemistry also revealed overexpression of Mina53 in gastric cancer, colon cancer, esophageal cancer, lymphoma, renal cell carcinoma, and neuroblastoma [18-27]. Mina53 
Table 3 Cell cycle distribution and apoptosis after 48 and $72 \mathrm{~h}$ of transfection (\%)

\begin{tabular}{|c|c|c|c|c|c|c|c|c|}
\hline \multirow[t]{2}{*}{ Groups } & \multicolumn{4}{|l|}{$48 \mathrm{~h}$} & \multicolumn{4}{|l|}{$72 \mathrm{~h}$} \\
\hline & Apoptosis rate & $\mathrm{G}_{0} / \mathrm{G}_{1}$ & $\mathrm{~S}$ & $\mathrm{G}_{2} / \mathrm{M}$ & Apoptosis rate & $\mathrm{G}_{0} / \mathrm{G}_{1}$ & S & $\mathrm{G}_{2} / \mathrm{M}$ \\
\hline Blank control & $0.7 \pm 0.4$ & $56.9 \pm 3.5$ & $32.2 \pm 2.9$ & $15.2 \pm 1.9$ & $0.8 \pm 0.6$ & $51.5 \pm 2.4$ & $30.8 \pm 2.3$ & $14.7 \pm 2.1$ \\
\hline Negative siRNA & $0.8 \pm 0.5$ & $55.2 \pm 2.8$ & $33.7 \pm 3.5$ & $16.4 \pm 1.8$ & $0.9 \pm 0.8$ & $50.7 \pm 2.7$ & $31.7 \pm 2.6$ & $15.6 \pm 1.9$ \\
\hline Mina53 siRNA & $19.3 \pm 2.8$ & $40.9 \pm 3.2$ & $19.9 \pm 2.9$ & $25.1 \pm 2.8$ & $38.9 \pm 2.9$ & $26.3 \pm 2.6$ & $9.2 \pm 2.9$ & $30.1 \pm 2.5$ \\
\hline
\end{tabular}

expression is inversely correlated with patient survival in esophageal cancer, renal cell carcinoma, and neuroblastoma. These results suggested that Mina53 may be involved in carcinogenesis and tumor progression which led us to hypothesize that Mina53 may be involved in abnormal cellular growth in pancreatic cancer.

Pancreatic cancer is one of the most aggressive malignancies with a very poor prognosis, partially due to a very difficult accessibility to resection and resistance to chemoradiotherapy [29]. As such, it is imperative to find more effective and specific therapies [30, 31]. Identification of specific targets can be done by RNA interference (RNAi) [32-34]. As a powerful tool to suppress gene expression in mammalian cells, the RNAi can be directed against pancreatic cancer through various pathways, including the inhibition of overexpressed oncogenes, suppression of tumor growth, metastasis, and enhancement of apoptosis [35, 36].

TMA allows researchers to investigate multiple specimens simultaneously using immunohistochemistry (IHC). Quantum dots (QDs) are semiconductor nanocrystals with a core/shell structure and a large spectral band gap that possess unique photodynamic properties such as size-tunable symmetric emission bands, strong light absorbance, high fluorescent intensity, and high photostability. The QD fluorescence can be separated from background autofluorescence in biological specimens, such as cells and tissues [37-44]. Many studies of molecular targeted imaging of cancer cells and molecules demonstrated the advantages of QD-IHC, such as supreme fluorescent efficiency, better signal clarity, and a higher sensitivity and accuracy compared with conventional immunohistochemistry techniques. Therefore, QD-IHC allows to gain better insights into tumor biology [45]. Based on these considerations, we used mouse anti-human Mina53 monoclonal antibody to study the expression of Mina53 in TMA of pancreatic cancer by QD-IHC. In this study, staining quality of images by QDs-IHC was significantly higher than conventional IHC. QD-IHC in our study showed that most of pancreatic cancer specimens exhibited elevated expression of Mina53. By contrast, only two normal pancreatic specimens showed weakly positive staining.

We observed that Mina53 expression is associated with lymph node metastasis, histological differentiation, and TNM stage. Therefore, Mina53 may play some role in pancreatic carcinogenesis and can thus be used as a marker for pancreatic cancer.

The siRNA silencing of Mina53 inhibited cell growth in a human colon cancer cell line SW620, and two human esophageal squamous cell carcinoma cell lines TE-9 and TE11, demonstrating that Mina53 plays an important role in cell growth [18, 19]. Increased expression of Mina53 is a characteristic feature in some cancer cells, therefore, targeting Mina53 may have therapeutic applications. In our study, Mina53 siRNA silencing successfully diminished pancreatic cancer cell growth. Thus, after 48 and $72 \mathrm{~h}$ of siRNA treatment, Mina53 siRNA inhibited the growth of PANC-1 cells by, respectively, 40 and $35 \%$. In addition, the silencing caused cell arrest in G2/M phase and induced apoptosis. This indicates that Mina53 gene may be one of the key factors involved in formation and development of pancreatic cancer. Therefore, Mina53 holds a promising therapeutic potential as a future treatment for pancreatic cancer and provides a theoretical basis for gene therapy of pancreatic cancer.

In conclusion, Mina53 is overexpressed in pancreatic cancer and is associated with cancer proliferation. Mina53 plays an important role in the carcinogenesis and development of pancreatic cancer. This protein can be used as a marker for pancreatic cancer and a target for treatment.

Open Access This article is distributed under the terms of the Creative Commons Attribution License which permits any use, distribution, and reproduction in any medium, provided the original author(s) and the source are credited.

\section{References}

1. Shin, E. J. (2012). Canto MI (2012) Pancreatic cancer screening. Gastroenterology Clinics of North America, 41, 143-157.

2. Hidalgo, M. (2010). Pancreatic cancer. New England Journal of Medicine, 362, 1605-1617.

3. Mortensen, M. B., \& Svolgaard, B. (2010). Odense MV (2010) [Diagnosis and assessment of pancreatic cancer]. Ugeskrift for Laeger, 172, 1369-1372.

4. Cascinu, S., Falconi, M., Valentini, V., \& Jelic, S. (2010). Pancreatic cancer: ESMO Clinical practice guidelines for diagnosis, treatment and follow-up. Annals of Oncology, 21(Suppl 5), v55-v58.

5. Mossner, J. (2010). What's new in therapy of pancreatic cancer? Digestive Diseases, 28, 679-683.

6. Renouf, D., \& Moore, M. (2010). Evolution of systemic therapy for advanced pancreatic cancer. Expert Review of Anticancer Therapy, 10, 529-540. 
7. DePinho, R., Mitsock, L., Hatton, K., Ferrier, P., Zimmerman, K., Legouy, E., et al. (1987). Myc family of cellular oncogenes. Journal of Cellular Biochemistry, 33, 257-266.

8. Dang, C. V. (1991). c-Myc oncoprotein function. Biochimica et Biophysica Acta, 1991(1072), 103-113.

9. Packham, G., \& Cleveland, J. L. (1995). c-Myc and apoptosis. Biochimica et Biophysica Acta, 1242, 11-28.

10. Tsujiuchi, T., Nakae, D., \& Konishi, Y. (2001). [Oncogene c-Myc]. Nihon Rinsho, 59(Suppl 6), 116-120.

11. Lutz, W., Leon, J., \& Eilers, M. (2002). Contributions of Myc to tumorigenesis. Biochimica et Biophysica Acta, 1602, 61-71.

12. Dang, C. V., O’Donnell, K. A., Zeller, K. I., Nguyen, T., Osthus, R. C., \& Li, F. (2006). The c-Myc target gene network. Seminars in Cancer Biology, 16, 253-264.

13. Albihn, A., Johnsen, J. I., \& Henriksson, M. A. (2010). MYC in oncogenesis and as a target for cancer therapies. Advances in Cancer Research, 107, 163-224.

14. Wolfer, A., \& Ramaswamy, S. (2011). MYC and metastasis. Cancer Research, 71, 2034-2037.

15. Luscher, B., \& Vervoorts, J. (2012). Regulation of gene transcription by the oncoprotein MYC. Gene, 494, 145-160.

16. Tsuneoka, M., Nishimune, Y., Ohta, K., Teye, K., Tanaka, H., Soejima, M., et al. (2006). Expression of Mina53, a product of a Myc target gene in mouse testis. International Journal of Andrology, 29, 323-330.

17. Tsuneoka, M., Koda, Y., Soejima, M., Teye, K., \& Kimura, H. (2002). A novel myc target gene, mina53, that is involved in cell proliferation. Journal of Biological Chemistry, 277, 35450-35459.

18. Teye, K., Tsuneoka, M., Arima, N., Koda, Y., Nakamura, Y., Ueta, Y., et al. (2004). Increased expression of a Myc target gene Mina53 in human colon cancer. American Journal of Pathology, 164, 205-216.

19. Tsuneoka, M., Fujita, H., Arima, N., Teye, K., Okamura, T., Inutsuka, H., et al. (2004). Mina53 as a potential prognostic factor for esophageal squamous cell carcinoma. Clinical Cancer Research, 10, 7347-7356.

20. Kuratomi, K., Yano, H., Tsuneoka, M., Sakamoto, K., Kusukawa, J., \& Kojiro, M. (2006). Immunohistochemical expression of Mina53 and Ki67 proteins in human primary gingival squamous cell carcinoma. Kurume Medical Journal, 53, 71-78.

21. Fukahori, S., Yano, H., Tsuneoka, M., Tanaka, Y., Yagi, M., Kuwano, M., et al. (2007). Immunohistochemical expressions of Cap43 and Mina53 proteins in neuroblastoma. Journal of Pediatric Surgery, 42, 1831-1840.

22. Ishizaki, H., Yano, H., Tsuneoka, M., Ogasawara, S., Akiba, J., Nishida, N., et al. (2007). Overexpression of the myc target gene Mina53 in advanced renal cell carcinoma. Pathology International, 57, 672-680.

23. Teye, K., Arima, N., Nakamura, Y., Sakamoto, K., Sueoka, E., Kimura, H., et al. (2007). Expression of Myc target gene mina53 in subtypes of human lymphoma. Oncology Reports, 18, 841-848.

24. Zhang, Q., Hu, C. M., Yuan, Y. S., He, C. H., Zhao, Q., \& Liu, N. Z. (2008). Expression of Mina53 and its significance in gastric carcinoma. International Journal of Biological Markers, 23, 83-88.

25. Komiya, K., Sueoka-Aragane, N., Sato, A., Hisatomi, T., Sakuragi, T., Mitsuoka, M., et al. (2010). Expression of Mina53, a novel c-Myc target gene, is a favorable prognostic marker in early stage lung cancer. Lung Cancer, 69, 232-238.

26. Komiya, K., Sueoka-Aragane, N., Sato, A., Hisatomi, T., Sakuragi, T., Mitsuoka, M., et al. (2010). Mina53, a novel c-Myc target gene, is frequently expressed in lung cancers and exerts oncogenic property in NIH/3T3 cells. Journal of Cancer Research and Clinical Oncology, 136, 465-473.

27. Ogasawara, S., Komuta, M., Nakashima, O., Akiba, J., Tsuneoka, M., \& Yano, H. (2010). Accelerated expression of a Myc target gene Mina53 in aggressive hepatocellular carcinoma. Hepatology Research, 40, 330-336.

28. Wikman, H., Seppanen, J. K., Sarhadi, V. K., Kettunen, E., Salmenkivi, K., Kuosma, E., et al. (2004). Caveolins as tumour markers in lung cancer detected by combined use of cDNA and tissue microarrays. The Journal of Pathology, 203, 584-593.

29. Hartman, D. J., \& Krasinskas, A. M. (2012). Assessing treatment effect in pancreatic cancer. Archives of Pathology and Laboratory Medicine, 136, 100-109.

30. Yachida, S. (2012). Novel therapeutic approaches in pancreatic cancer based on genomic alterations. Current Pharmaceutical Design, 18, 2452-2463.

31. Petersen, G. M., \& Boffetta, P. (2012). Carcinogenesis of pancreatic cancer: challenges, collaborations, progress. Molecular Carcinogenesis, 51, 1-2.

32. Vaccaro, V., Gelibter, A., Bria, E., Iapicca, P., Cappello, P., Di, M. F., et al. (2012). Molecular and genetic bases of pancreatic cancer. Current Drug Targets, 13, 731-743.

33. Philip, P. A. (2008). Targeted therapies for pancreatic cancer. Gastrointestinal Cancer Research, 2, S16-S19.

34. Porzner, M., \& Seufferlein, T. (2011). Novel approaches to target pancreatic cancer. Current Cancer Drug Targets, 11, 698-713.

35. Bandiera, S., Barrey, E., Ernoult-Lange, M., Gidrol, X., HenrionCaude, A., Huang, L., et al. (2012). [Mitochondria, microRNA and RNA interference]. Medicine Sciences (Paris), 28, 23-26.

36. Ashihara, E. (2010). [RNA interference for cancer therapies]. Gan To Kagaku Ryoho, 37, 2033-2041.

37. Tomczak, N., Janczewski, D., Dorokhin, D., Han, M. Y., \& Vancso, G. J. (2012). Enabling biomedical research with designer quantum dots. Methods in Molecular Biology, 811, 245-265.

38. Wang, Y., \& Chen, L. (2011). Quantum dots, lighting up the research and development of nanomedicine. Nanomedicine, 7 , 385-402.

39. Rosenthal, S. J., Chang, J. C., Kovtun, O., McBride, J. R., \& Tomlinson, I. D. (2011). Biocompatible quantum dots for biological applications. Chemistry \& Biology, 18, 10-24.

40. Zhang, L., Xing, Y., He, N., Zhang, Y., Lu, Z., Zhang, J., et al. (2012). Preparation of graphene quantum dots for bioimaging application. Journal of Nanoscience and Nanotechnology, 12, 2924-2928.

41. Hong, L., Wang, Z., Yuan, L., Tan, J., Wang, L., Qu, G., et al. (2012). Subcellular distribution of CdSe quantum dots (QDs) in breast cancer cells. Journal of Nanoscience and Nanotechnology, $12,365-367$.

42. Li, H., Li, M., Shih, W. Y., Lelkes, P. I., \& Shih, W. H. (2011). Cytotoxicity tests of water soluble $\mathrm{ZnS}$ and $\mathrm{CdS}$ quantum dots. Journal of Nanoscience and Nanotechnology, 11, 3543-3551.

43. Peng, L. L., Wang, Y. H., \& Li, C. Y. (2010). Ultraviolet-blue photoluminescence of $\mathrm{ZnSe}$ quantum dots. Journal of Nanoscience and Nanotechnology, 10, 2113-2118.

44. Wang, Y. H., Chen, Z., \& Zhou, X. Q. (2008). Synthesis and photoluminescence of $\mathrm{ZnS}$ quantum dots. Journal of Nanoscience and Nanotechnology, 8, 1312-1315.

45. Li, Z. H., Peng, J., \& Chen, H. L. (2011). Bioconjugated quantum dots as fluorescent probes for biomedical imaging. Journal of Nanoscience and Nanotechnology, 11, 7521-7536. 